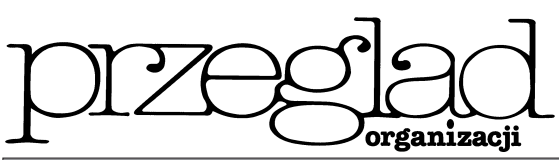

\title{
Motywy podejmowania działalności gospodarczej na przykładzie badanych przedsiębiorców województwa podkarpackiego
}

https://doi.org/10.33141/po.2005.78.11

\section{Teresa Piecuch}

\section{Wprowadzenie}

D ecyzja o podjęciu działalności gospodarczej nie jest rzeczą łatwą. W każdym przypadku pozostawia trwały ślad w psychice, dalszym życiu zawodowym i prywatnym przedsiębiorcy. Wynika z sumy posiadanej wiedzy, osobistych doświadczeń, przemyśleń oraz pojawiających się w otoczeniu możliwości. Zawsze przypomina coś, co F. Schutze ${ }^{1)}$ nazywa „metamorfozą biograficzną”, a co znacząco i na trwałe zmienia przyszłe życie przedsiębiorcy.

Interesująca wydaje się zatem analiza motywów podjęcia działalności gospodarczej. Pełnią one rolę mechanizmów pobudzających do działania. Stanowią specyficzne, wewnętrzne źródło motywacji, skłaniające do przejawiania określonej aktywności.

Celem opracowania jest identyfikacja i charakterystyka najważniejszych motywów podejmowania działalności gospodarczej. Analiza ta opiera się na badaniach własnych autorki przeprowadzonych wśród 492 przedsiębiorców województwa podkarpackiego. Dotyczyły one uwarunkowań rozwoju przedsiębiorczości. Na podstawie zgromadzonego materiału empirycznego możliwe było również określenie przyczyn podejmowania działalności gospodarczej przez respondentów.

\section{Charakterystyka badanej populacji przedsiębiorców}

W ażne w przypadku analizy motywów podejmowania działalności gospodarczej mogą okazać się niektóre socjodemograficzne cechy przedsiębiorców, takie jak: wiek, płeć, wykształcenie, pochodzenie. Wskazują one okoliczności, które doprowadziły do podjęcia decyzji o założeniu firmy. Identyfikują społeczne uwarunkowania rozwoju przedsiębiorczości w danym obszarze. Według T. Kraśnickiej²) zmienne te oddziałują na decyzje przedsiębiorcze, rodzaj prowadzonej działalności gospodarczej, nawet na jej efektywność.

Większość badań dotyczących przedsiębiorczości dowodzi, że aktywni gospodarczo są przede wszystkim ludzie młodzi. Twierdzi tak na przykład A.S.
Przegląd Organizacji, Nr 7/8 (786/787), 2005, ss. 43-46 www.przegladorganizacji.pl Towarzystwo Naukowe Organizacji i Kierownictwa (TNOiK)
Marcinkowski, dla którego „przedsiębiorczość jest fenomenem silnie związanym z kategorią wieku"3). Badania, na których oparto się w opracowaniu, są pod tym względem nieco odmienne. Większość respondentów to osoby w wieku od 40 do 45 lat oraz od 45 do 50 lat") (tabela 1).

Analizując płeć respondentów stwierdzono, że bardziej przedsiębiorczy są mężczyźni, stanowili oni 74,6\% respondentów. Potwierdzają to również badania $\mathrm{T}$. Kraśnickiej j). Uważa ona jednak, że fakt ten nie wynika z różnic psychologicznych - jej zdaniem jest to spowodowane raczej czynnikami zewnętrznymi, w tym także kulturowymi.

Ważną rolę (zwłaszcza w pozycji nowo założonego przedsiębiorstwa na rynku) odgrywa też wykształcenie przedsiębiorcy. Wiedza powoduje, że jest on bardziej otwarty na nowości, wpływa to na jego zachowania, stosunek do innych ludzi, otaczającej go rzeczywistości. Badani przedsiębiorcy byli dość dobrze wykształceni. Najliczniejszą grupę stanowiły bowiem osoby z wykształceniem średnim - 45,5\%. Wielu legitymowało się też wykształceniem wyższym - 34,8\% przypadków. Można więc powtórzyć za A.S. Marcinkowskim $^{6}$, że w badanym obszarze wyższe wykształcenie stanowiło okoliczność sprzyjającą decyzji o podjęciu działalności gospodarczej.

Ważne jest też pochodzenie, które zwraca uwagę na przedsiębiorczą aktywność (bądź jej brak) określo-

Tab. 1. Wiek badanych przedsiębiorców

\begin{tabular}{|l|c|}
\hline \multicolumn{1}{|c|}{ Wyszczególnienie } & Procent odpowiedzi \\
\hline Do 25 lat & $\mathbf{5 , 3 \%}$ \\
\hline Od 25 do 30 lat & $\mathbf{1 2 , 4 \%}$ \\
\hline Od 30 do 35 lat & $\mathbf{1 4 , 4 \%}$ \\
\hline Od 35 do 40 lat & $\mathbf{1 5 , 0} \%$ \\
\hline Od 40 do 45 lat & $\mathbf{2 2 , 4 \%}$ \\
\hline Od 45 do 50 lat & $\mathbf{1 8 , 9 \%}$ \\
\hline Powyżej 50 lat & $\mathbf{1 1 , 6 \%}$ \\
\hline
\end{tabular}

Źródło: opracowanie własne na podstawie wyników badań empirycznych. 
nych grup społecznych. Ma to również związek z występowaniem (bądź nie) na danym obszarze kultury przedsiębiorczości. Najwięcej badanych pochodziło z rodzin robotniczych $-43,7 \%$ przypadków, nieco mniej z inteligenckich $-27,2 \%$. Okazuje się zatem, że te środowiska są (z konieczności, czy z wewnętrznej potrzeby) najbardziej przedsiębiorcze.

Przeprowadzone badania wykazały, że przedsiębiorcy województwa podkarpackiego są grupą - pod wieloma względami - różnorodną. Miało to zapewne wpływ na motywy, jakimi kierowali się podejmując działalność gospodarczą.

\section{Identyfikacja najważniejszych motywów podejmowania działalności gospodarczej badanych przedsiębiorców województwa podkarpackiego}

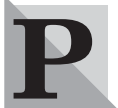

roblem motywacji przedsiębiorczych jest bardzo wielowymiarowy. Przedsiębiorca jest jednostką złożoną, kieruje się wieloma motywami uporządkowanymi zgodnie $\mathrm{z}$ indywidualnym systemem potrzeb i wartości. Najważniejsze motywy badanych przedsiębiorców prezentuje tabela 2 .

\section{Brak pracy}

Dominującym motywem w przypadku badanej populacji okazał się brak pracy - wskazało na niego $32,2 \%$ respondentów. Być może osoby te nie posiadały odpowiednich do bycia przedsiębiorcą predyspozycji, nie były do końca przekonane o słuszności swoich wyborów, nie posiadały koniecznej wiedzy. Mimo to zdecydowały się na założenie przedsiębiorstwa. Z badań wynika, że najczęściej byli to przedsiębiorcy w wieku

Tab. 2. Motywy podejmowania dziatalności gospodarczej

\begin{tabular}{|r|l|c|}
\hline Lp. & \multicolumn{1}{|c|}{ Wyszczególnienie } & $\begin{array}{c}\text { Procent } \\
\text { odpo- } \\
\text { wiedzi }\end{array}$ \\
\hline 1. & Życiowa konieczność - brak pracy & $\mathbf{3 2 , 2}$ \\
\hline 2. & Dobry pomysł na działalność gospodarczą & $\mathbf{1 7 , 2}$ \\
\hline 3. & Chęć osiągnięcia maksymalnego zysku & $\mathbf{1 1 , 0}$ \\
\hline 4. & Potrzeba osiągnięć & $\mathbf{8 , 0}$ \\
\hline 5. & Odpowiednia ilość „wolnej” gotówki & $\mathbf{6 , 4}$ \\
\hline 6. & Potrzeba szacunku & $\mathbf{4 , 5}$ \\
\hline 7. & Chęć dorobienia (do pensji, emerytury) & $\mathbf{4 , 2}$ \\
\hline 8. & Odpowiedni lokal & $\mathbf{3 , 8}$ \\
\hline 9. & Potrzeba władzy & $\mathbf{3 , 2}$ \\
\hline 10. & Potrzeba niezależności & $\mathbf{3 , 0}$ \\
\hline $\mathbf{1 1}$ & Potrzeba samorealizacji & $\mathbf{2 , 4} *$ \\
\hline
\end{tabular}

*) W sumie $4,1 \%$ badanych nie udzieliło odpowiedzi na to pytanie lub stwierdziło, że nie miało wyjścia - firmę otrzymało w spadku. Respondenci zostali poproszeni o wskazanie tylko jednego, dominującego w ich przypadku motywu, stąd procent odpowiedzi sumuje się do 100.

Źródło: opracowanie własne na podstawie wyników badań empirycznych. od 30 do 35 lat oraz od 40 do 45 lat (następne grupy wiekowe od 45 do 50 lat oraz powyżej 50 lat), a więc osoby już niemłode, które z różnych przyczyn od siebie niezależnych utraciły pracę i zmuszone były radzić sobie z zaistniała sytuacją. Były to w znacznej większości osoby ze średnim wykształceniem (a więc bez zawodu), nie posiadające żadnych rodzinnych tradycji przedsiębiorczości (nie majace zatem wsparcia w członkach rodzin), co zapewne dodatkowo utrudniało ich sytuację. Mimo to zdecydowały się „wziąć sprawy w swoje ręce”, podjęły ryzyko i założyły własne firmy.

Dla największego odsetka badanych decyzja o podjęciu „pracy na swoim” spowodowana była więc motywacją negatywną. Działania przedsiębiorcze zostały wymuszone zaistniałą sytuacją. W grę wchodziły zapewne: utrata pracy, pogorszenie sytuacji materialnej (wynikające z tego lęki, niepokoje, frustracje), a więc presja zachodzących w życiu, niekorzystnych zmian, które spowodowały wytworzenie się negatywnego bodźca, wymuszającego konkretne działania. Według K. Majewskiej i S. Owczarek ${ }^{7}$, wśród małych i średnich przedsiębiorstw powstajacych w wyniku motywacji negatywnej (jeżeli oczywiście nie zostanie następnie wzbudzona motywacja pozytywna), występuje największy odsetek upadłości. Prawdopodobny jest też niewielki rozwój tych firm oraz to, że nie będac one tworzyły nowych miejsc pracy. Jeżeli uda im się rozwinąć działalność, to jedynie po to, by zapewnić miejsca pracy dla przedsiębiorcy oraz najbliższej jego rodziny. Dążyć będą jedynie do przetrwania, nie do ekspansji działalności, do rozwoju realizowanych przedsięwzięć.

\section{Pomysł na działalność gospodarczą}

Ważny w przypadku respondentów okazał się dobry pomysł na działalność gospodarczą - 17,2\% wskazań (jak sami stwierdzali: często „dojrzewający” latami). Posiadanie własnego, nawet bardzo małego przedsiębiorstwa jest zapewne marzeniem wielu ludzi. Jednak jego urzeczywistnienie uzależnione jest w głównej mierze od znalezienia odpowiedniego pomysłu, w następnej kolejności od skutecznej jego realizacji. Potwierdza to S. Makarski, zdaniem którego „przedsiębiorczość jest złożonym procesem, rozpoczynającym się od przemyśleń, wnioskowań i pomysłów innowacyjnych poprzez fazę działania, do konkretnych celów"8).

Pomysł jest kombinacją konkretnych możliwości przedsiębiorcy oraz zaobserwowanych potrzeb otoczenia; dobry, może decydować o pozycji nowego przedsiębiorstwa na rynku. Twierdzą tak A. Rogut i A. Rzetelska ${ }^{9}$, dla których właściwy pomysł we właściwym czasie jest pierwszym, ważnym krokiem na drodze do osiągnięcia sukcesu przez przedsiębiorcę.

Najwięcej osób, które wskazały na ten motyw, posiadało wykształcenie średnie, ale tylko nieco mniej z nich wyższe. Należy zatem przypuszczać, że przedsiębiorcy ci byli merytorycznie przygotowani do roli przedsiębiorcy, posiadali niezbędną do tego wiedzę, dysponowali odpowiednimi predyspozycjami, ich decyzja była świadoma, przemyślana. Najwięcej z nich posiadało także w rodzinie wzorce przedsiębiorczości, 
co mogło być dla nich dużym ułatwieniem. Mogli liczyć na pomoc, wsparcie, zrozumienie. Dla wielu z nich nie było to też pierwsze przedsięwzięcie, a drugie, trzecie, a nawet czwarte. Może to świadczyć o tym, że czuli się „prawdziwymi” przedsiębiorcami, którzy nie zrażają się niepowodzeniami, którzy „odradzają się” w innym przedsięwzięciu nawet, jeżeli ich przedsiębiorstwo upada.

W przypadku tej grupy przedsiębiorców decydujące znaczenie odegrały motywacje pozytywne, nie zmuszające, a zachęcające do przejawiania aktywności. Pełnią one rolę dynamicznych bodźców, samonapędzających do działania. Przedsiębiorca motywowany pozytywnie dąży do rozwoju założonego przez siebie przedsiębiorstwa, do ekspansji na nowe rynki, dywersyfikowania działalności. Jego aktywność jest korzystna nie tylko dla niego samego, ale i dla jego otoczenia. Ciagle stawia sobie nowe, ambitniejsze cele, jest aktywnym, dynamicznym twórcą kreującym rzeczywistość wokół siebie.

\section{Chęć osiągnięcia maksymalnego zysku}

Badania wykazały, że ważny dla przedsiębiorców był również maksymalny zysk - 11\% wskazań. Podjęcie pracy na własny rachunek umożliwia uzyskanie samodzielności i niezależności finansowej. Zysk dla przedsiębiorców jest zatem zapewne ważny. Często są to osoby, które do założenia firmy zmusiła utrata pracy. Głównym bodźcem ich działalności jest więc zysk, dający poczucie materialnego bezpieczeństwa, gwarantujący zaspokojenie ich potrzeb. Wiadomo również, że każdy przedsiębiorca woli uzyskiwać więcej niż mniej zysku, zawsze więc kieruje się jawnym, bądź (może częściej) ukrytym motywem zysku.

$\mathrm{W}$ literaturze przedmiotu dążenie do osiagania maksymalnych korzyści ekonomicznych przez przedsiębiorców jest mocno krytykowane. Wskazuje się, że zysk nie powinien stanowić jedynego, najważniejszego celu funkcjonowania przedsiębiorstw, że nie powinno traktować się go jako przyczyny działań przedsiębiorczych - raczej jako ich skutek. Podkreśla się też, że chęć osiągnięcia maksymalnego zysku może być związana z osiąganiem go za wszelką cenę, wszelkimi sposobami, co może być bardzo niebezpieczne - zwłaszcza dla zatrudnionych w takich przedsiębiorstwach pracowników. Z drugiej strony, samo dążenie do zysku nie musi być niczym złym. Nie należy tego potępiać. Zysk pełni bowiem rolę „...czynnika mobilizującego, wyzwalającego energię, pomysłowość, wysiłek, kreującego różne formy działalności ludzkiej (...) Uzyskane korzyści są ważnym atutem działań przedsiębiorczych, ale niekoniecznie musi to być (nie powinien to być) cel najważniejszy"10).

Okazuje się, że w analizowanym obszarze motyw zysku jest dość mocno zakorzeniony. Być może wynika to też z dużych trudności z pozyskaniem zewnętrznych źródeł finansowania. Wygospodarowane zyski przedsiębiorcy często przeznaczają na finansowanie bieżącej działalności - nie na inwestycje, rozwój, a tym bardziej na konsumpcję. W takiej sytuacji jak największa kwota zysku jest gwarancją przetrwania, bezpiecznego funkcjonowania małych przedsiębiorstw w przyszłości. W takiej sytuacji dążenie do zysku wydaje się jak najbardziej uzasadnione.

\section{Potrzeby: osiągnięć, szacunku, władzy, samorealizacji}

Dla 8\% respondentów ważna okazała się potrzeba osiagnięć, czyli „...dążenie do uczestniczenia w działaniach, które dają tego rodzaju zadowolenie - uzyskiwanie czegoś w wyniku wysiłków"11). Jej wynikiem jest wytrwałe podejmowanie działań, przezwyciężanie przeszkód, pokonywanie trudności i osiąganie wytyczonego sobie celu, który zazwyczaj jest bardzo ambitny. W życiu prywatnym, jak i w działalności gospodarczej kieruje takimi osobami ciągły, nieustający pęd, niespożyta energia, wewnętrzna determinacja i jednocześnie ogromna satysfakcja z realizacji zamierzeń i z ich „owoców” - wymiernych i niewymiernych.

Potrzeba osiagnięć pobudza do działania, motywuje do długotrwałych wysiłków, ciągle pcha człowieka do działania, rozwijania się, poszerzania umiejętności, rywalizowania z innymi, a przede wszystkim z samym sobą - w przypadku przedsiębiorcy jest (powinna być) bardzo rozwinięta. W przypadku respondentów nie okazała się jednak zbyt ważna.

Jeszcze mniejsze znaczenie odgrywała potrzeba szacunku, jakim cieszą się osoby decydujace się na trud bycia przedsiębiorca $-4,5 \%$ wskazań. Prestiż wynika zarówno z tego, że docenia się wysiłki skierowane na utrzymanie przedsiębiorstw, sumienność, pracowitość przedsiębiorców oraz to, że biorą oni na siebie często duże ryzyko działalności, że mimo bardzo niesprzyjających warunków zewnętrznych ich przedsiębiorstwa funkcjonują, dają zatrudnienie innym.

Bez wątpienia ważna dla przedsiębiorców powinna być także potrzeba władzy związana $\mathrm{z}$ chęcia przewodzenia innym, wpływania na ich postępowanie. Przedsiębiorca chce dominować, podporzadkowuje sobie ludzi i środki, żeby osiagnać konkretne cele związane z funkcjonowaniem jego przedsiębiorstwa. Chce przyciągać uwagę innych, „[...] szuka aplauzu i usilnie dąży do tego, by być docenionym"12). W literaturze przedmiotu z tego zakresu dowodzi się, że u przedsiębiorców potrzeba dominacji jest bardzo mocno rozwinięta, że często motyw ten jest czynnikiem decydującym o podjęciu „pracy na swoim”. Ważne jest to, że mogą być niezależni, że nie będą musieli się podporządkowywać, nikt nie będzie nad nimi dominował, niczego nie będzie im narzucał, a nawet przeciwnie to oni będą władni, by takie stosunki kreować, sami zajmując pozycję nadrzędną w hierarchii. W badanym obszarze motyw ten nie odgrywał jednak dużej roli dla jedynie $3,2 \%$ populacji potrzeba ta zadecydowała o założeniu własnego przedsiębiorstwa.

Niewielu respondentów uznało też potrzebę samorealizacji za najważniejszy motyw $-2,4 \%$. Bardzo wielu naukowców uznaje ją za najważniejszą w hierarchii potrzeb przedsiębiorcy - na przykład R.D. Hisrich i M.P. Peters czy M. Mc Clelland ${ }^{13)}$. Potrzeba ta wyraża się w dążeniu przedsiębiorcy do pełnego zrealizowania własnych możliwości, osiągnięcia pełni rozwoju, wyróżnienia się z otoczenia, pozwala uzyskać satysfakcję $\mathrm{z}$ realizowania zaplanowanego przez siebie przedsięwzięcia, z urzeczywistniania własnych planów i ambicji, z udowodnienia innym, a szczególnie sobie swojej operatywności, skuteczności, aktywności, odwagi. Według A. Maslowa potrzeba samorealizacji 
ważna jest dla każdego człowieka, nawet z punktu widzenia jego zdrowia psychicznego - jest bowiem szczytem jego hierarchii potrzeb i wartości. Jego zdaniem każdy dąży do tego, by „[...] być tym, czym może być, chce dowieść, że jest coś wart" ${ }^{14)}$. Zakłócenia w realizacji tej potrzeby mogą negatywnie wpływać na stan psychiczny człowieka, na jego prawidłowe funkcjonowanie. W praktyce okazało się, że nie odgrywała ona jednak tak dużego znaczenia.

\section{Zakończenie}

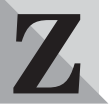
aprezentowana charakterystyka motywów podejmowania działalności gospodarczej, to jedynie jeden $\mathrm{z}$ wielu przykładów potrzeb niewątpliwie ważnych dla przedsiębiorcy - nie oznacza to jednak, że są one identyczne u wszystkich. Niemożliwe jest bowiem sformułowanie uniwersalnego „zestawu" potrzeb charakteryzujących wszystkich przedsiębiorców. Każdy z nich jest inny, w każdym przypadku na jego życiowe wybory wpływają inne motywy, których określona kombinacja składa się na decyzję o podjęciu i prowadzeniu działalności gospodarczej.

$\mathrm{Na}$ podstawie przeprowadzonych badań można także stwierdzić, że większością badanych kierowały motywacje negatywne, wymuszające określone zachowanie, przejawiające się w chęci zapewnienia środków do życia przedsiębiorcy i jego rodzinie. Motywacje pozytywne, stwarzające dużo większe możliwości rozwojowe dla tworzonych firm, związane na przykład z generowaniem nowych miejsc pracy, ekspansją działalności - należały do rzadkości ${ }^{15)}$.

dr Teresa Piecuch Zakład Przedsiębiorczości i Zarządzania, Wydział Zarządzania i Marketingu Politechniki Rzeszowskiej

\section{PRZYPISY}

1) F. SCHUTZE, Pressure and Guilt: War Experiences of a Young German Soldier and their Biographical Implications, „International Sociology” 1992, nr 2, s. 187.

2) T. KRAŚNICKA, Koncepcja rozwoju przedsiębiorczości ekonomicznej i pozaekonomicznej, Wyd. AE w Katowicach, Katowice 2002, s. 93.

3) Kapitalizm po polsku. Przedsiębiorca. Kultura. Organi$z a c j a$, pod red. A.S. MARCINKOWSKIEGO, Wyd. Profesjonalnej Szkoły Biznesu w Krakowie, Kraków 1996, s. 97 i dalsze.

4) Znajduje to potwierdzenie $\mathrm{w}$ opiniach pracowników instytucji wspierania przedsiębiorczości. Ich zdaniem województwo podkarpackie dysponuje nie wykorzystanym potencjałem w postaci dużej liczby coraz lepiej wykształconych młodych ludzi (więcej niż połowa mieszkańców regionu nie przekroczyła 33 lat), którzy jednak niechętnie decydują się na podjęcie działalności gospodarczej. Coraz więcej ludzi młodych wybiera nawet dużo gorzej płatną pracę najemną, nie podejmuje ryzyka założenia własnej firmy.

5) T. KRAŚNICKA, Koncepcja rozwoju przedsiębiorczości..., op.cit., s. 94.

6) Kapitalizm po polsku. Przedsiębiorca. Kultura. Organizacja, op.cit., s. 95.

7) K. MAJEWSKA, S. OWCZAREK, Rola przedsiębiorczości w podnoszeniu konkurencyjności firmy. Analiza przy- padku, [w:] Przedsiębiorczość $i$ twórcze myślenie w biznesie, pod red. S. RUDOLFA, Łódź 2002, s. 30.

8) S. MAKARSKI, Cztowiek a przedsiębiorczość w gospodarce rynkowej, [w:] Przedsiębiorczość $w$ procesie transformacji, pod red. K. JAREMCZUKA, Wyd. WSAiZ w Przemyślu, Przemyśl 2000, s. 503.

9) Ekonomika i zarzadzanie mata firma, pod red. B. PIASECKIEGO, PWN, Warszawa 1998, s. 121.

10) A.P. WIATRAK, Pojęcie przedsiębiorczości, jej cele i rodzaje, [w:] Uwarunkowania rozwoju przedsiębiorczości..., op.cit., s. 30.

11) R.A. WEBBER, Podstawy zarzadzania organizacjami, PWE, Warszawa 1990, s. 52.

12) L.V. RYAN, Bariery osobowościowe w osiaganiu sukcesu, „Businessman” 1992, nr 12, s. 77.

13) R.D. HISRICH, M.P. PETERS, Entrepreneurship. Starting. Developing and Managing a New Enterprise, Boston, 1989, s. 62.

14) Socjologia i psychologia pracy, pod red. J. BUGLA, PWN, Warszawa 1987, s. 33.

15) Należy także zwrócić uwagę na bardzo korzystną dla gospodarki tendencję, której niestety nie ujawniono w trakcie badań w województwie podkarpackim (przypadków takich jest także wciąż niewiele w skali kraju), kiedy zakładają przedsiębiorstwa specjaliści odchodzący z innych przedsiębiorstw, pracujący do tej pory jako pracownicy najemni. Według H. Frańczak. istotnie zmienia to rynek, sprawia, że staje się on bardziej profesjonalny. Ważne jest także to, że jest to doskonała zachęta dla innych, którzy decydują się stworzyć miejsca pracy nie tylko dla siebie, ale i dla innych. Odejście z dużej firmy, a następnie założenie własnego przedsiębiorstwa ujawnia także najbardziej poszukiwany, pożądany w gospodarce talent - przedsiębiorczość - źródło: M. KLIMKOWSKI, E. MISTEWICZ, Wielkie ucieczki, „Wprost” 2000, nr 939.

\section{BIBLIOGRAFIA}

[1] Ekonomika i zarzadzanie mata firma, pod red. B. PIASECKIEGO, PWN, Warszawa 1998.

[2] HISRICH R. D., PETERS M. P., Entrepreneurship. Starting. Developing and Managing a New Enterprise, Boston 1989.

[3] Kapitalizm po polsku. Przedsiębiorca. Kultura. Organizacja, pod red. A. S. MARCINKOWSKIEGO, Wyd. Profesjonalnej Szkoły Biznesu w Krakowie, Kraków 1996.

[4] KLIMKOWSKI M., MISTEWICZ E., Wielkie ucieczki, „Wprost” 2000, nr 939.

[5] KRAŚNICKA T., Koncepcja rozwoju przedsiębiorczości ekonomicznej i pozaekonomicznej, Wyd. AE w Katowicach, Katowice 2002.

[6] Przedsiębiorczość i twórcze myślenie w biznesie, pod red. S. RUDOLFA, Łódź 2002.

[7] Przedsiębiorczość $w$ procesie transformacji, pod red. K. JAREMCZUKA, Wyd. WSAiZ w Przemyślu, Przemyśl 2000. [8] RYAN L. V., Bariery osobowościowe w osiaganiu sukcesu, „Businessman” 1992, nr 12.

[9] SCHUTZE F., Pressure and Guilt: War Experiences of a Young German Soldier and their Biographical Implications, „International Sociology” 1992, nr 2.

[10] Socjologia i psychologia pracy, pod red. J. BUGLA, PWN, Warszawa 1987.

[11] Uwarunkowania rozwoju przedsiębiorczości - szanse i zagrożenia, pod red. K. JAREMCZUKA, Wyd. PWSZ w Tarnobrzegu, Tarnobrzeg 2003.

[12] WEBBER R. A., Podstawy zarzadzania organizacjami, PWE, Warszawa 1990. 